\title{
Individual tree and stand-level carbon and nutrient contents across one rotation of loblolly pine plantations on a reclaimed surface mine
}

\author{
Hannah Z. Angel ${ }^{1,2}$ D $\cdot$ Jeremy S. Priest ${ }^{1,3} \cdot$ Jeremy P. Stovall $^{1} \cdot$ Brian P. Oswald $^{1}$. \\ Yuhui Weng $^{1} \cdot$ Hans M. Williams ${ }^{1}$
}

Received: 18 March 2018 / Accepted: 11 December 2018 / Published online: 17 December 2018

(c) The Author(s) 2018

\begin{abstract}
While reclaimed loblolly pine (Pinus taeda L.) plantations in east Texas, USA have demonstrated similar aboveground productivity levels relative to unmined forests, there is interest in assessing carbon (C) and nutrients in aboveground components of reclaimed trees. Numerous studies have previously documented aboveground biomass, $\mathrm{C}$, and nutrient contents in loblolly pine plantations; however, similar data have not been collected on mined lands. We investigated $\mathrm{C}, \mathrm{N}, \mathrm{P}, \mathrm{K}, \mathrm{Ca}$, and $\mathrm{Mg}$ aboveground contents for firstrotation loblolly pine growing on reclaimed mined lands in the Gulf Coastal Plain over a 32-year chronosequence and correlated elemental rates to stand age, stem growth, and similar data for unmined lands. At the individual tree level, we evaluated elemental contents in aboveground biomass components using tree size, age, and site index as predictor variables. At the stand-level, we then scaled individual tree $\mathrm{C}$ and nutrients and fit a model to determine the sensitivity of aboveground elemental contents to stand age and site index. Our data suggest that aboveground $\mathrm{C}$ and nutrients in loblolly pine on mined lands exceed or follow similar trends to data for unmined pine plantations derived from the literature. Diameter and height were the best predictors of individual tree stem $\mathrm{C}$ and nutrient contents $(R \geq 0.9473$ and 0.9280 , respectively) followed by stand age $(R \geq 0.8660)$. Foliage produced weaker relationships across all predictor variables compared to stem, though still significant $(P \leq 0.05)$. The model for estimating stand-level $\mathrm{C}$ and nutrients using stand age provided a good fit, indicating that contents aggrade over time predictably. Results of this study show successful modelling of reclaimed loblolly pine aboveground $\mathrm{C}$ and nutrients, and suggest elemental cycling is comparable to unmined lands, thus providing applicability of our model to related systems.
\end{abstract}

Keywords Aboveground carbon · Nitrogen · Phosphorus · Reforestation · Pinus taeda L.

Hannah Z. Angel

angelhz@vt.edu

1 Arthur Temple College of Forestry and Agriculture, Stephen F. Austin State University, Nacogdoches, TX 75962, USA

2 Present Address: School of Plant and Environmental Sciences, Virginia Polytechnic Institute and State University, Blacksburg, VA 24061, USA

3 Present Address: Arlington, TX 76012, USA 


\section{Introduction}

Reclaiming forests on surface mined lands serves as a springboard for carbon (C) sequestration, restoration of composition and ecological function, and provides economic opportunities such as timber and bioenergy production (Zipper et al. 2011). These benefits are universal to several avenues of land restoration following human-caused disturbances (Nave et al. 2018). Surface mining removes and alters native pre-existing topsoil, which must be carefully salvaged to avoid major losses (Hall et al. 2010; Zipper et al. 2013). Consequently, surface mine reclamation creates potential for additional soil organic $\mathrm{C}$ sequestration and storage over longer periods of time, especially on high quality forested sites (Amichev et al. 2008; Ussiri and Lal 2005). Amichev et al. (2008) demonstrated that ecosystem $\mathrm{C}$ sequestration on mined lands are capable of meeting pre-mining levels. Previously published allometric relationships for loblolly pine trees growing on reclaimed mined lands in the Gulf Coastal Plain showed increased biomass and volume growth over time, with growth rates similar to non-mined lands (Priest et al. 2015).

Loblolly pine (Pinus taeda L.) is the most commonly planted tree species in the southern USA, where commercial pine plantations are a major reason that the region accounts for $60 \%$ of the nation's timber production (Prestemon and Abt 2002). In the Gulf Coastal Plain, forestry is commonly chosen as the post-mining land use, particularly loblolly pine plantations (Priest et al. 2015). Pine forests sequestered 85\% more ecosystem C compared to hardwood and mixed forest stands across USA coalfields in midwestern and eastern regions (Amichev et al. 2008). There is considerable interest in the long-term $\mathrm{C}$ storage potential of intensely managed loblolly pine plantations given the species' extensive geographic range, fast growth rates, and high stand productivity (Aspinwall et al. 2012; Maier et al. 2004). The potential response of loblolly pine to global climate change further highlights its importance. Loblolly pine productivity and disease resilience is evidenced to increase with predicted rises in carbon dioxide concentrations (Loehle et al. 2016).

Nutrients and $\mathrm{C}$ in aboveground biomass components for loblolly pine growing on nonmined lands have been well documented both within and across growing seasons (Adegbidi et al. 2005; Albaugh et al. 2012; Barron-Gafford et al. 2003; Van Lear et al. 1984; Zhang and Allen 1996; Zhao et al. 2014), although studies conducted on mined lands are limited. Research has focused primarily on ecosystem $\mathrm{C}$ sequestration on reforested mined lands versus unmined reference sites (Amichev et al. 2008; Shrestha and Lal 2006), and distribution and accumulation of $\mathrm{C}$ and nutrients in reclaimed mine soils over time (Akala and Lal 2001; Chatterjee et al. 2009; Chichester and Smith 1983; Howard et al. 1988; Li and Daniels 1994; Shrestha and Lal 2007). Zipper et al. (2007) estimated the potential of ecosystem $\mathrm{C}$ accumulation on reclaimed mined sites if reforested. Based on previously published forest productivity and soil data, they showed that reforesting mined lands to pine and/or mixed stands would provide faster and greater $\mathrm{C}$ accumulation compared to hardwood stands. Other studies have correlated mine soil nutrients and other properties to forest tree productivity on mined and unmined lands (Rodrigue and Burger 2004), to seedling growth (Showalter et al. 2007), and to early tree performance (Andrews et al. 1998).

Mined land reclamation studies across the world have found that within about a decade following placement, mine soils begin to develop genetic horizons and accumulate organic carbon (Ciolkosz et al. 1985; Haering et al. 2004; Maharana and Patel 2013). Plant growth media used in mine reclamation may include topsoil and/or overburden (e.g., surface and subsurface materials) given that physical, chemical, and mineralogical properties are deemed suitable (Angel 1973; Daniels and Amos 1985; Hons 1978). All forms of surface 
mining utilize reclamation methods of transporting, storing, and handling topsoil and/or overburden materials. These processes inherently decrease important soil nutrients and organic matter, and disrupt natural soil microbial communities (Shrestha and Lal 2006). $\mathrm{Ng}$ (2012) found that within 5 years soil $\mathrm{C}$ and $\mathrm{N}$ concentrations returned to pre-mining baseline conditions, whereas soil $\mathrm{C}$ and $\mathrm{N}$ returned to biological fractions after 16 years. They also showed that soil macronutrient $(\mathrm{K}, \mathrm{Ca}, \mathrm{Mg})$ concentrations increased with time (within 20 years) and exceeded pre-mining conditions, except for soil P. This study was also conducted in the Gulf Coastal Plain and strengthened knowledge of mine soil $\mathrm{C}$ and nutrient distribution over time. Despite this information, our understanding of how nutrient cycling processes are reflected in aboveground woody plant tissues is limited.

While several researchers have developed weight-to-volume equations for loblolly pine (Baldwin 1987; Gonzalez-Benecke et al. 2014; Metz and Wells 1965; Newbold et al. 2001; Van Lear and Kapeluck 1995), fewer studies rely on direct measurements when modelling individual tree and stand-level $\mathrm{C}$ and nutrient aggradation over time. Johnson et al. (2003) directly measured $\mathrm{C}$ and $\mathrm{N}$ in soil and vegetation in a loblolly pine ecosystem over 18 years. A study in North Carolina on loblolly pine $\mathrm{C}$ cycling also used direct methods for measuring C (Kinerson et al. 1977). Another study directly measured aboveground energy and $\mathrm{C}$ contents in 12-year-old loblolly pine (Zhao et al. 2014). A universally applied estimate of average aboveground $\mathrm{C}$ in woody biomass is 50\% (Avera et al. 2015; Johnsen et al. 2004; Jones and O'Hara 2016; Justine et al. 2015; Maier et al. 2004). Using the 50\% C average, Maier et al. (2004) found that fertilized 12-year-old loblolly pine stands served as carbon sinks compared to non-fertilized stands which remained sources. Studies in China (Justine et al. 2015) and Canada (Peichl and Arain 2006) used similar experimental designs to our study, although they did not utilize direct measurements for aboveground tree $\mathrm{C}$. For accurate estimates, there is a need to directly quantify tree $\mathrm{C}$ and nutrient concentrations over extended periods of time.

Further information on temporal changes in loblolly pine tree biomass $\mathrm{C}$ and nutrients may strengthen our understanding of carbon sequestration and nutrient availability in managed loblolly pine plantations on reclaimed mined lands. Our objectives were to: (1) examine $\mathrm{C}$ and macronutrient $(\mathrm{N}, \mathrm{P}, \mathrm{K}, \mathrm{Ca}, \mathrm{Mg}$ ) concentrations in two aboveground biomass components (stem and foliage) of first-rotation reclaimed loblolly pine plantations across a full rotation chronosequence; (2) evaluate the relationship of individual tree $\mathrm{C}$ and nutrient contents by biomass component to more easily measured predictor variables (stand age, site index, tree diameter and height); (3) assess the impact of stand age and site index on stand-level $\mathrm{C}$ and nutrient contents; and, (4) compare data from this study to unmined lands derived from the literature to determine the impact of surface mining on aboveground loblolly pine $\mathrm{C}$ and nutrient accumulation.

\section{Materials and methods}

\section{Study site}

The study site was located at the Beckville Mine, an active lignite surface mine owned by the Luminant Mining Company, LLC (Luminant). The mine covers 12,000 ha in Rusk and Panola counties, Texas (N32¹4'20.7414", W94 29'44.9262") (Priest et al. 2015). Premining soils consisted of Paleudults (Bowie, Lilbert, Kullit, and Darco series), Hapludults (Kirvin, Cuthbert, Sacul, and Tenaha series), and Udifluvents (Iuka series) (Dolezel 1975). 
The climate of the site is characterized as sub-tropical humid with mixed hardwood and evergreen cover types. Mean annual rainfall is $1306 \mathrm{~mm}$ with a temperature mean high of $24.6{ }^{\circ} \mathrm{C}$ and an annual average temperature of $18.4{ }^{\circ} \mathrm{C}$ (National Oceanic and Atmospheric Administration 2016).

\section{Stand characteristics and inventory}

A chronosequence approach was used to develop models of accumulating elemental contents in first-rotation loblolly pine plantations based on forestry inventory and individual tree biomass data previously described in Priest et al. (2015). Following reclamation at the Beckville Mine, the approximate original contour was returned with mixed overburden materials. Agricultural lime was previously applied to the mixed overburden. Chemical and mechanical site preparation included initial seeding with an herbaceous cover crop mix (e.g., one legume and non-legume spp.), fertilizer application (e.g., pelletized 17-1717), and operational tillage (30-35 cm depth) using a tractor-pulled Rome disk. Bare-root loblolly pine seedlings were machine planted on a $2 \mathrm{~m} \times 3 \mathrm{~m}$ spacing. We identified 47 stands ranging in age from 3 to 32 years post-planting. Some of the older stands were low thinned while younger stands were unthinned. At each of the 47 stands, a forest inventory plot was installed that was 0.1 ha in size $(20 \mathrm{~m} \times 50 \mathrm{~m})$. Stands were measured in May and June 2013 with a 100\% inventory within each plot collecting diameter $(\mathrm{cm})$ at breast height $(1.3 \mathrm{~m})$, or DBH, and total height on each planted pine. Stand-level inventory and biomass data were averaged by age class (Table 1). While our study focused solely on planted loblolly pine, low quantities of herbaceous plants, small hardwood trees, and woody vines were generally present in the understory (Priest et al. 2015). Generally, competing vegetation on reclaimed pine plantations in the Gulf Coastal Plain is minimal compared to unmined lands (Priest et al. 2015). Several site-specific criteria considered suitable for chronosequence studies have been addressed in our study (Walker et al. 2010). However, we did not account for within stage variation in our age-sequence by establishing and subsequently measuring permanent plots over time, and thus recognize this as a limitation.

\section{Destructive sampling}

As previously described in Priest et al. (2015), aboveground destructive sampling occurred during dormancy in December 2013 through January 2014. At each plot, one dominant or co-dominant tree randomly selected from the 10 tallest trees in the inventory plot was felled by chainsaw near ground line or between 0.3 and $1.3 \mathrm{~m}$ for large trees. Living and dead branches were removed from the bole. Three living branches were sampled, one each from the top, middle, and lower crown portions for each tree. All living branches were weighed using a hanging electronic MSI-7200 Dyna-Link dynamometer rated to $907 \mathrm{~kg}$ (Measurement Systems International, Seattle, WA) in the field to derive a total combined wet weight for live branches, foliage, and seed cones. Similarly, each tree bole was sectioned and weighed green in the field. Boles were sectioned by chainsaw at $0.46 \mathrm{~m}$ and $1.37 \mathrm{~m}$, and then at every $1.22 \mathrm{~m}$ increment above $1.37 \mathrm{~m}$ to a minimum top diameter of $0.64 \mathrm{~cm}$. Stem-disks $(5 \mathrm{~cm}$ thick) were removed at each section cut by chainsaw. Only the disks taken at DBH and at the highest section were used in this study. Data derived from both stem-disks were averaged per tree as observational units. Whole-tree aboveground green weight was later converted to oven-dried biomass following drying of subsamples of each tissue in the laboratory. Stands with harvested trees with a $\mathrm{DBH}<6.0 \mathrm{~cm}$ were 


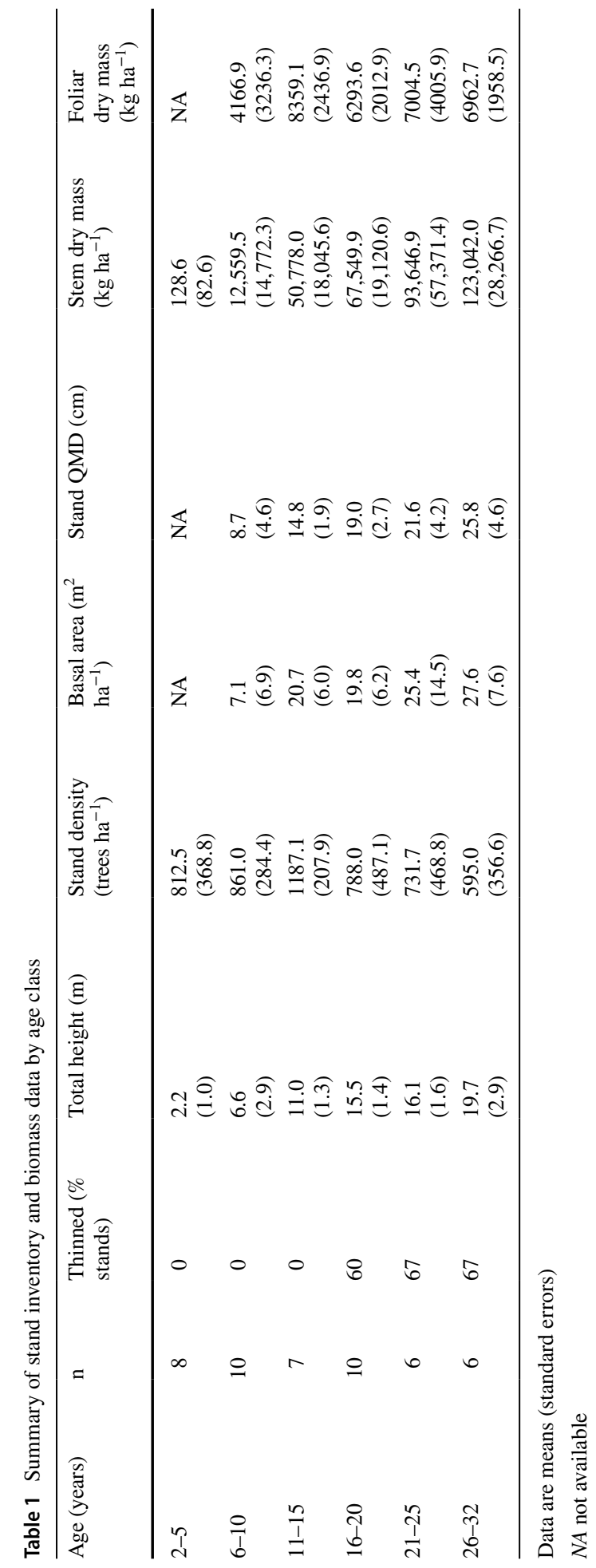


excluded from stem analyses resulting in 38 trees analyzed for the stem tissue component. For the foliar tissue component, a lack of sufficient sample volume reduced the number of samples, resulting in a total of 40 trees analyzed.

\section{Carbon and nutrient concentrations}

Samples were transferred to the laboratory and placed in cold storage at $4{ }^{\circ} \mathrm{C}$. Branches were sectioned into various biomass components (live needles, live/dead branches, and seed cones). Initial wet weights of the stem-disks were taken using a Mettler-Toledo PB3002-S/FACT (Mettler-Toledo, Inc., Columbus, OH). All biomass components were then oven-dried at $65{ }^{\circ} \mathrm{C}$ to constant weight. Wet weight to oven-dried weight and component (branches, foliage, cones) weight to total weight ratios of the three branch samples were used to scale weights to a whole-tree, oven-dried basis by tissue component. Three foliar subsamples were randomly selected for each of the 47 trees. Excluding the bark, stem-disk samples were cut into representable wedge-shaped pieces and then into smaller pieces for grinding. Approximately 6-10 $\mathrm{g}$ of biomass was ground from each disk using a Thomas-Wiley Model 4 Mill (Thomas Scientific, USA). Macronutrient (P, K, Ca, Mg) concentrations were quantified with an Optical Emission Spectrometry Inductively Coupled Plasma (ICP-OES) analyzing unit (Thermo Scientific, USA) following extraction by the Mehlich III extraction procedure (Mehlich 1984). Total carbon and nitrogen concentrations were measured using a LECO CHN628 Series Elemental Determinator (St. Joseph, MI). Nutrient and carbon concentrations were quantified on each subsample, averaged by tissue, then scaled to an individual tree dry-mass basis expressed as $\mathrm{kg} \mathrm{tree}^{-1}$. Individual trees were scaled to stand-level using previously published allometric relationships of DBH and height (Priest et al. 2015). Stand-level C and nutrient contents were the product of elemental concentrations and total tissue component biomass for the sample plot and expressed as $\mathrm{g} \mathrm{m}^{-2}$. Using the model (1) shown below, carbon and nutrient contents were estimated for each inventoried tree per sample plot from a previous dataset (Priest et al. 2015).

\section{Statistical analyses}

All statistical analyses were performed using SAS (SAS 9.3, SAS Institute, Cary, NC) with $\alpha=0.05$. Data were transformed by natural $\log (\ln )$ and assumptions of normality assessed using PROC UNIVARIATE. At the individual tree level, carbon and nutrients were fitted against the following predictor variables using simple linear regression in PROC REG: age since planting, site index, $\mathrm{DBH}$, and total tree height. We adapted a nonlinear model form based on dry weight relationships for loblolly pine trees growing in north Louisiana (Newbold et al. 2001) to provide a fit for stand-level $\mathrm{C}$ and nutrient estimates. The outcome of this model provided a sensitivity analysis for correlating stand age and site index to aboveground elemental contents in loblolly pine:

$$
\ln E=\beta 0+\beta 1 \operatorname{In}(d)+\beta 2 \operatorname{In}(h)+\beta 3 a^{2}+\beta 4 \operatorname{In}(s i)
$$

where $E=$ elemental content $\left(\mathrm{g} \mathrm{m}^{-2}\right), d=$ tree diameter $(\mathrm{cm}), h=$ total tree height $(\mathrm{m})$, $a=$ stand age since planting (years), $s i=$ site index $(\mathrm{m})$, and $\beta 0, \beta 1, \beta 2, \beta 3, \beta 4=$ estimated regression parameters. Model regression parameters were estimated using PROC NLIN. Visual (residual plots) and formal (Levene's test) diagnostics were examined for individual and stand-level regression fitting. Based on the model fit, we examined the impact of age and site index on stand-level carbon and nutrient contents using simple linear regression as 
outlined above. Unthinned plots were not included in the stand-level analyses, resulting in a sample size of 29 stands for the age variable and 16 stands for site index. The lower sample size for the site index variable was a result of removing younger trees $(<10$ years) from the stand-level analysis; younger trees were also removed from individual tree analyses with site index as the independent variable. Younger trees were removed due to the poor ability to predict age 25 site index from trees this young (see Priest et al. 2016, Fig. 8).

We relied on previously published data (Albaugh et al. 2010; Rubilar et al. 2005; Zhao et al. 2014) from unmined lands to assess our fourth objective since loblolly pine carbon and nutrient concentration data has been well documented in the literature. Using data (mean, sample size, variance) from these studies, we constructed $95 \%$ confidence intervals to assess differences in elemental concentrations between mined and unmined lands. While confidence intervals that did not overlap were treated as statistically significant differences, for overlapping confidence intervals, we evaluated the confidence interval for the difference between means for mined and unmined elemental concentrations by calculating the $\mathrm{t}$-statistic for each mean comparison using $\alpha=0.01$ and $\mathrm{t}$-value $=2.58$. This $\alpha$ was selected based on the number of comparisons and associated type I error rates.

\section{Results}

\section{Tissue-level elemental concentrations}

Loblolly pine $\mathrm{C}$ and nutrient elemental concentrations and biomass data were averaged by age class for each tissue component (Table 2). Critical foliar concentrations of N, P, K, Ca and $\mathrm{Mg}$ established for loblolly pine trees are $1.20,0.12,0.30,0.15$ and 0.08 percent, respectively (Jokela 2004). Foliar nutrients were either at or above these critical concentrations when averaged across age classes for individual trees (Table 3). Elemental concentrations for individual tree stem and foliar biomass components were referenced to unmined concentrations reported for 12-year-old loblolly pine plantations growing in the Upper Coastal Plain and Piedmont regions in Georgia (Zhao et al. 2014), first-rotation 22-year-old loblolly pine growing in the Upper Coastal Plain in Alabama (Rubilar et al. 2005), and for loblolly pine plantations from several studies across the southeastern USA (Albaugh et al. 2010). Stem C was higher on mined lands, whereas foliar $\mathrm{C}$ was similar between mined and unmined lands. While stem $\mathrm{C}$ was within the range (45-54\% C dry weight) reported in the literature for loblolly pine (Kinerson et al. 1977), both tissue components did not match commonly used conversion factors in the literature for estimating C biomass: $50 \%$ for wood and $45 \%$ for foliage (Zhao et al. 2014) (Table 3). Stem Ca was higher on mined lands when compared to unmined lands in Zhao et al. (2014). All other stem nutrient concentrations were higher on mined lands except for stem $\mathrm{P}$, which was similar to unmined lands. Foliar N concentration was higher on some unmined lands compared to mined lands (Zhao et al. 2014); however, when compared to Albaugh et al. (2010) and Rubilar et al. (2005), foliar N was higher on mined lands. Foliar P concentrations were similar between mined and unmined lands (Albaugh et al. 2010; Zhao et al. 2014), with an exception of Rubilar et al. (2005). Mined lands had higher foliar K than Albaugh et al. (2010) and Zhao et al. (2014), whereas foliar K was similar to Rubilar et al. (2005). Calcium and $\mathrm{Mg}$ concentrations in foliage were all higher on mined lands compared to studies conducted on unmined lands (Table 3), which is not surprising given that these mine soils were limed as part of the reclamation process. 
Table 2 Elemental concentrations and dry mass data for stem and foliar tissue components by age class

\begin{tabular}{|c|c|c|c|c|c|c|c|c|c|}
\hline Tissue & Age (years) & $\mathrm{n}$ & $\mathrm{C}(\%)$ & $\mathrm{N}(\%)$ & $\mathrm{P}(\%)$ & $\mathrm{K}(\%)$ & $\mathrm{Ca}(\%)$ & $\operatorname{Mg}(\%)$ & $\begin{array}{l}\text { Dry mass } \\
\left(\mathrm{kg} \mathrm{tree}^{-1}\right)\end{array}$ \\
\hline \multirow[t]{6}{*}{ Stem } & $2-5$ & NA & NA & NA & NA & NA & NA & NA & NA \\
\hline & $6-10$ & 10 & $\begin{array}{l}46.1 \\
(0.1)\end{array}$ & $\begin{array}{l}0.36 \\
(0.03)\end{array}$ & $\begin{array}{l}0.02 \\
(0.01)\end{array}$ & $\begin{array}{l}0.15 \\
(0.05)\end{array}$ & $\begin{array}{l}0.10 \\
(0.02)\end{array}$ & $\begin{array}{l}0.16 \\
(0.02)\end{array}$ & $\begin{array}{l}21.8 \\
(20.2)\end{array}$ \\
\hline & $11-15$ & 6 & $\begin{array}{l}46.2 \\
(0.4)\end{array}$ & $\begin{array}{l}0.34 \\
(0.02)\end{array}$ & $\begin{array}{l}0.01 \\
(0.00)\end{array}$ & $\begin{array}{l}0.09 \\
(0.03)\end{array}$ & $\begin{array}{l}0.09 \\
(0.01)\end{array}$ & $\begin{array}{l}0.14 \\
(0.02)\end{array}$ & $\begin{array}{l}58.7 \\
(19.0)\end{array}$ \\
\hline & $16-20$ & 10 & $\begin{array}{l}46.1 \\
(0.5)\end{array}$ & $\begin{array}{l}0.34 \\
(0.04)\end{array}$ & $\begin{array}{l}0.01 \\
(0.00)\end{array}$ & $\begin{array}{l}0.10 \\
(0.03)\end{array}$ & $\begin{array}{l}0.09 \\
(0.02)\end{array}$ & $\begin{array}{l}0.15 \\
(0.02)\end{array}$ & $\begin{array}{l}149.0 \\
(52.9)\end{array}$ \\
\hline & $21-25$ & 6 & $\begin{array}{l}45.7 \\
(0.5)\end{array}$ & $\begin{array}{l}0.35 \\
(0.03)\end{array}$ & $\begin{array}{l}0.01 \\
(0.00)\end{array}$ & $\begin{array}{l}0.10 \\
(0.02)\end{array}$ & $\begin{array}{l}0.10 \\
(0.01)\end{array}$ & $\begin{array}{l}0.15 \\
(0.01)\end{array}$ & $\begin{array}{l}182.3 \\
(98.2)\end{array}$ \\
\hline & $26-32$ & 6 & $\begin{array}{l}46.6 \\
(0.8)\end{array}$ & $\begin{array}{l}0.35 \\
(0.04)\end{array}$ & $\begin{array}{l}0.01 \\
(0.00)\end{array}$ & $\begin{array}{l}0.08 \\
(0.01)\end{array}$ & $\begin{array}{l}0.09 \\
(0.01)\end{array}$ & $\begin{array}{l}0.14 \\
(0.01)\end{array}$ & $\begin{array}{l}307.4 \\
(129.1)\end{array}$ \\
\hline \multirow[t]{6}{*}{ Foliar } & $2-5$ & 6 & $\begin{array}{l}48.1 \\
(0.4)\end{array}$ & $\begin{array}{l}1.26 \\
(0.13)\end{array}$ & $\begin{array}{l}0.11 \\
(0.01)\end{array}$ & $\begin{array}{l}0.56 \\
(0.13)\end{array}$ & $\begin{array}{l}0.40 \\
(0.06)\end{array}$ & $\begin{array}{l}0.23 \\
(0.06)\end{array}$ & $\begin{array}{l}1.59 \\
(1.37)\end{array}$ \\
\hline & $6-10$ & 10 & $\begin{array}{l}47.8 \\
(0.4)\end{array}$ & $\begin{array}{l}1.29 \\
(0.16)\end{array}$ & $\begin{array}{l}0.11 \\
(0.02)\end{array}$ & $\begin{array}{l}0.50 \\
(0.12)\end{array}$ & $\begin{array}{l}0.35 \\
(0.04)\end{array}$ & $\begin{array}{l}0.20 \\
(0.04)\end{array}$ & $\begin{array}{l}5.49 \\
(2.78)\end{array}$ \\
\hline & $11-15$ & 6 & $\begin{array}{l}47.8 \\
(0.6)\end{array}$ & $\begin{array}{l}1.34 \\
(0.16)\end{array}$ & $\begin{array}{l}0.13 \\
(0.01)\end{array}$ & $\begin{array}{l}0.50 \\
(0.05)\end{array}$ & $\begin{array}{l}0.29 \\
(0.05)\end{array}$ & $\begin{array}{l}0.19 \\
(0.05)\end{array}$ & $\begin{array}{l}7.72 \\
(3.38)\end{array}$ \\
\hline & $16-20$ & 9 & $\begin{array}{l}47.5 \\
(0.5)\end{array}$ & $\begin{array}{l}1.33 \\
(0.11)\end{array}$ & $\begin{array}{l}0.12 \\
(0.01)\end{array}$ & $\begin{array}{l}0.49 \\
(0.09)\end{array}$ & $\begin{array}{l}0.30 \\
(0.04)\end{array}$ & $\begin{array}{l}0.21 \\
(0.04)\end{array}$ & $\begin{array}{l}14.45 \\
(8.38)\end{array}$ \\
\hline & $21-25$ & 5 & $\begin{array}{l}48.2 \\
(0.2)\end{array}$ & $\begin{array}{l}1.32 \\
(0.12)\end{array}$ & $\begin{array}{l}0.12 \\
(0.01)\end{array}$ & $\begin{array}{l}0.51 \\
(0.11)\end{array}$ & $\begin{array}{l}0.28 \\
(0.05)\end{array}$ & $\begin{array}{l}0.18 \\
(0.05)\end{array}$ & $\begin{array}{l}13.43 \\
(9.76)\end{array}$ \\
\hline & $26-32$ & 4 & $\begin{array}{l}47.6 \\
(0.8)\end{array}$ & $\begin{array}{l}1.39 \\
(0.17)\end{array}$ & $\begin{array}{l}0.13 \\
(0.01)\end{array}$ & $\begin{array}{l}0.54 \\
(0.09)\end{array}$ & $\begin{array}{l}0.31 \\
(0.04)\end{array}$ & $\begin{array}{l}0.18 \\
(0.04)\end{array}$ & $\begin{array}{l}15.52 \\
(6.38)\end{array}$ \\
\hline
\end{tabular}

Data are means (standard errors)

$N A$ not available

\section{Individual tree elemental contents}

The relationship between loblolly pine elemental contents and stand age was significant for each tissue component; however, the stem component provided a better fit as indicated by relatively higher $R$ values (Fig. 1, Table 4). Tree size (DBH and height) provided the best overall fits for all $\mathrm{C}$ and nutrient contents in the stem component (Fig. 1, Table 4). For tree size and age predictor variables, the regression lines exhibited similar trends among all elements analyzed for stem and foliar components. The relationships between $\mathrm{Ca}$ and $\mathrm{Mg}$ and tree size for the foliar component were slightly weaker compared to other elemental contents (lower $R$ values). There were very weak relationships between elemental contents and site index for stem and foliar components (Fig. 1, Table 4).

\section{Stand-level elemental contents}

All model parameter estimates were significant $(P \leq 0.05)$ and may be applicable for estimating loblolly pine aboveground $\mathrm{C}$ and nutrient contents in areas with similar climates 


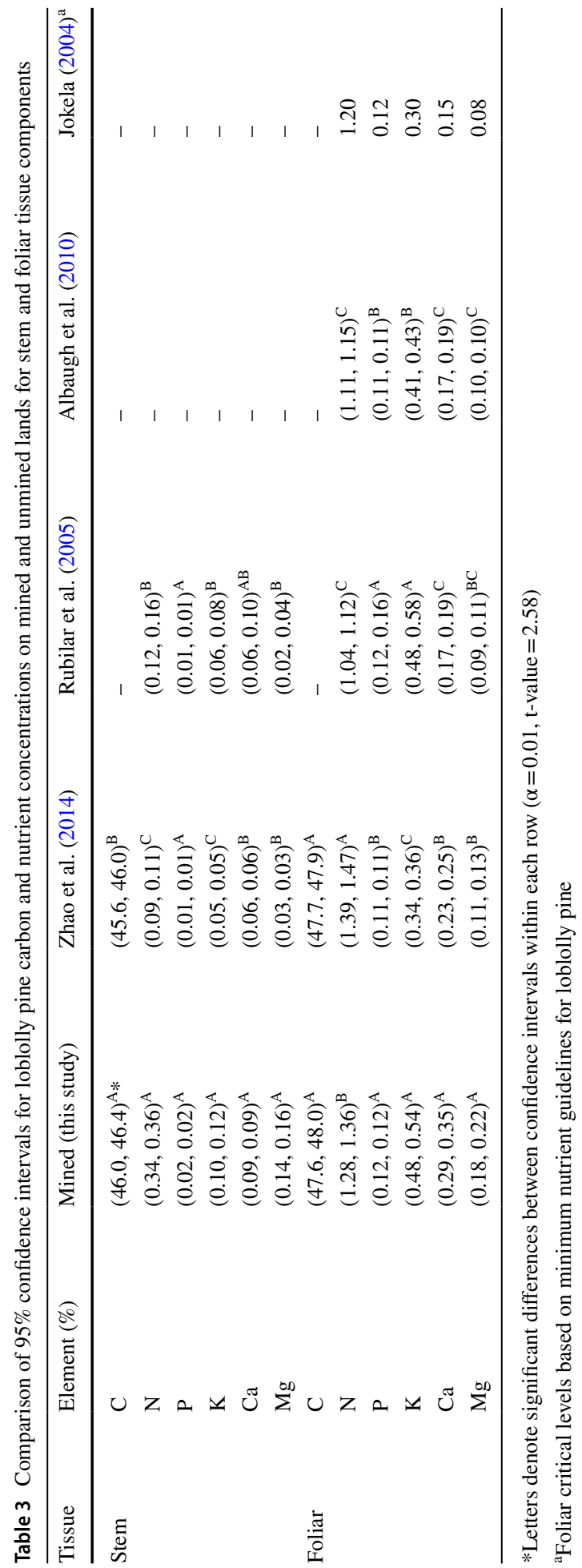



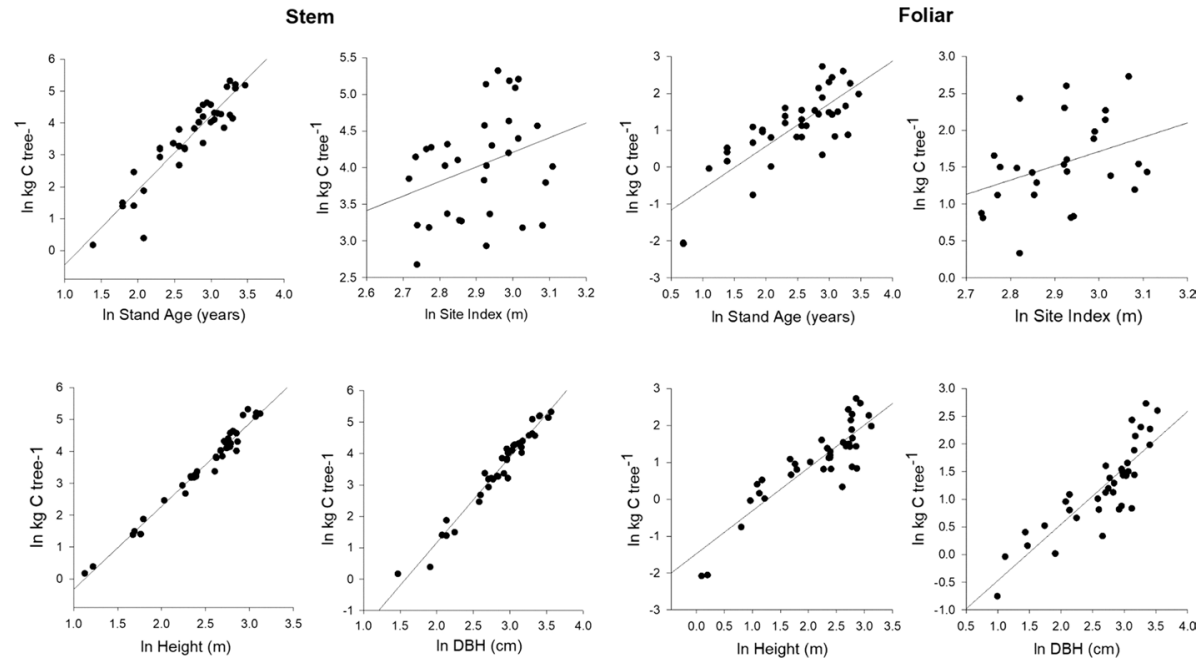

Fig. 1 Natural log of individual tree aboveground $\mathrm{C}$ versus stand age (years), diameter (cm) at breast height $(1.3 \mathrm{~m})$, total tree height $(\mathrm{m})$, and site index $(\mathrm{m})$ for stem and foliar biomass components at a surface mine in east Texas $(\alpha=0.05)$

and soil conditions (Table 5). At the stand-level, the model (1) produced overall good fits for estimating $\mathrm{C}$ and nutrients in tissue components using stand age (Fig. 2, Table 6), particularly for the stem component as indicated by higher adjusted- $R^{2}$ values for the model $(\geq 0.8599)$ with root mean square errors ranging from $(\ln ) 0.4097$ to 0.5133 years (Table 5). Residuals for the model (1) per biomass component are shown in Fig. 3 for aboveground C. Model predictions for nutrients displayed similar residual plot trends. Additionally, changes in elemental contents were highly significant over time and similarly increasing trends were shown between all elements analyzed for each tissue component. For each biomass component, the model was less sensitive to site index, provided poor fits, and was nonsignificant across elements (Fig. 2, Table 6). Carbon and nutrient concentration did not substantially change in stem and foliar components over time for any of the elements analyzed, but rather the changes in nutrient content are driven by tree growth and size, not changes in elemental concentration.

\section{Discussion}

\section{Elemental cycling in aboveground tree components}

Assessing changes in aboveground tree $\mathrm{C}$ and nutrients over many years may provide information regarding ecosystem recovery following a disturbance (Amichev et al. 2008; Shrestha and Lal 2007), and may also inform and improve forest management strategies (Zhao et al. 2014). At the landscape-level, research on C cycling in loblolly pine ecosystems has been extensive (Kinerson et al. 1977) and studies generally show that managed loblolly pine plantations accumulate $\mathrm{C}$ and nutrients predominately in aboveground 
Table 4 Pearson correlation coefficient matrix for individual tree aboveground elements and predictor variables for stem and foliar biomass components at a surface mine in east Texas

\begin{tabular}{|c|c|c|c|c|c|c|c|c|c|c|}
\hline Variables & 1. & 2. & 3. & 4. & 5. & 6. & 7. & 8. & 9. & 10 \\
\hline \multicolumn{11}{|l|}{ Stem } \\
\hline 1. Stand age (years) & - & & & & & & & & & \\
\hline 2. $\mathrm{DBH}^{\mathrm{a}}(\mathrm{cm})$ & $.8840^{*}$ & - & & & & & & & & \\
\hline 3. Total height (m) & $.8728 *$ & $.9580 *$ & - & & & & & & & \\
\hline 4. Site index (m) & -.1497 & $.3705^{*}$ & .3144 & - & & & & & & \\
\hline 5. $\mathrm{C}\left(\mathrm{kg} \operatorname{tree}^{-1}\right)$ & $.9247 *$ & $.9806^{*}$ & $.9875^{*}$ & .3198 & - & & & & & \\
\hline 6. $\mathrm{N}\left(\mathrm{kg}\right.$ tree $\left.^{-1}\right)$ & $.9218^{*}$ & $.9795^{*}$ & $.9827 *$ & .3447 & $.9975^{*}$ & - & & & & \\
\hline 7. $\mathrm{P}\left(\mathrm{kg}\right.$ tre $\left.\mathrm{e}^{-1}\right)$ & $.8660^{*}$ & $.9473 *$ & $.9280 *$ & $.4209 *$ & $.9522 *$ & $.9665^{*}$ & - & & & \\
\hline 8. $\mathrm{K}\left(\mathrm{kg}\right.$ tree $\left.^{-1}\right)$ & $.8694 *$ & $.9502 *$ & $.9352 *$ & $.4041^{*}$ & $.9585^{*}$ & $.9689^{*}$ & $.9883^{*}$ & - & & \\
\hline 9. $\mathrm{Ca}\left(\mathrm{kg}\right.$ tree $\left.^{-1}\right)$ & $.9331 *$ & $.9770 *$ & $.9829 *$ & .2582 & $.9942 *$ & $.9928^{*}$ & $.9495^{*}$ & $.9485^{*}$ & - & \\
\hline 10. $\mathrm{Mg}\left(\mathrm{kg}\right.$ tree $\left.^{-1}\right)$ & $.9298 *$ & $.9794 *$ & $.9831^{*}$ & .2890 & $.9958 *$ & $.9960^{*}$ & $.9603 *$ & $.9630 *$ & $.9986^{*}$ & - \\
\hline \multicolumn{11}{|l|}{ Foliar } \\
\hline 1. Stand age (years) & - & & & & & & & & & \\
\hline 2. $\mathrm{DBH}^{\mathrm{a}}$ & $.9073^{*}$ & - & & & & & & & & \\
\hline 3. Total height (m) & $.9587 *$ & $.9779 *$ & - & & & & & & & \\
\hline 4. Site index (m) & -.2329 & .3193 & .2290 & - & & & & & & \\
\hline 5. $\mathrm{C}\left(\mathrm{kg}\right.$ tree $\left.^{-1}\right)$ & $.8050 *$ & $.8580 *$ & $.8809^{*}$ & .3670 & - & & & & & \\
\hline 6. $\mathrm{N}\left(\mathrm{kg}_{\operatorname{tree}}^{-1}\right)$ & $.8057^{*}$ & $.8520 *$ & $.8748 *$ & .3318 & $.9956 *$ & - & & & & \\
\hline 7. $P\left(k g\right.$ tree $\left.{ }^{-1}\right)$ & $.8184^{*}$ & $.8602 *$ & $.8841^{*}$ & .3073 & $.9940 *$ & $.9970^{*}$ & - & & & \\
\hline 8. $\mathrm{K}\left(\mathrm{kg}\right.$ tree $\left.^{-1}\right)$ & $.8016^{*}$ & $.8147^{*}$ & $.8581^{*}$ & .2823 & $.9829 *$ & $.9869^{*}$ & $.9884^{*}$ & - & & \\
\hline 9. $\mathrm{Ca}\left(\mathrm{kg}\right.$ tree $\left.{ }^{-1}\right)$ & $.7089 *$ & $.7314 *$ & $.7970 *$ & .3577 & $.9690 *$ & $.9603^{*}$ & $.9534 *$ & $.9387 *$ & - & \\
\hline 10. $\mathrm{Mg}\left(\mathrm{kg}\right.$ tre $\left.^{-1}\right)$ & $.7622 *$ & $.8023^{*}$ & $.8387^{*}$ & .2846 & $.9747^{*}$ & $.9687^{*}$ & $.9657^{*}$ & $.9477 *$ & $.9688^{*}$ & - \\
\hline
\end{tabular}

$* P \leq 0.05$

${ }^{a}$ Diameter $(\mathrm{cm})$ at breast height $(1.3 \mathrm{~m})$

components (Adegbidi et al. 2005; Maier et al. 2004). Maier et al. (2004) found that ecosystem $\mathrm{C}$ storage was generally a product of increased $\mathrm{C}$ accumulation in the woody and foliar biomass of loblolly pine. These aboveground trends are similar to tree species growing in other regions. For example, carbon pools were evaluated in white pine (Pinus strobus L.) plantations in Canada and results showed aboveground tree biomass served as the greatest contributor to aboveground ecosystem C (Peichl and Arain 2006). Research involving $\mathrm{C}$ and nutrients in pine and hardwood tree biomass using a chronosequence approach extends worldwide (Gholz et al. 1985; Justine et al. 2015; Peichl and Arain 2006; Wang et al. 1995). In southwestern China, total tree biomass $\mathrm{C}$ in managed stands of Pinus massoniana L. rapidly increased in younger stands (3-12 years), and as trees matured (29-42 years) biomass $\mathrm{C}$ accumulated at much slower rates (Justine et al. 2015). Similarly, Wang et al. (1995) found that aboveground tree component $\mathrm{N}, \mathrm{Ca}, \mathrm{K}, \mathrm{Mg}$, and P increased with increasing ages of Populus tremuloides Michx. stands (5-95 years), with fastest accumulation rates occurring in younger stands. These studies, coupled with our model statistics, reinforce the strong relationship observed between stand age and stand-level $\mathrm{C}$ and nutrient accumulation.

Based on our stand-level estimates, elemental contents aggrade in loblolly pine stem and foliar tissue components over time, indicating that observed stand-level patterns are 
Table 5 Regression parameter estimates with standard errors for stem and foliar biomass components for model (1)

\begin{tabular}{lllllll}
\hline Parameter estimates & $\mathrm{C}$ & $\mathrm{N}$ & $\mathrm{P}$ & $\mathrm{K}$ & $\mathrm{Ca}$ & $\mathrm{Mg}$ \\
\hline Stem & & & & & & \\
$\beta_{0}$ & -0.3440 & -0.2042 & 0.4541 & -0.2920 & -0.3518 & -0.2831 \\
$\beta_{1}$ & $(0.5463)$ & $(0.5195)$ & $(0.5594)$ & $(0.6509)$ & $(0.6030)$ & $(0.5589)$ \\
& 10.4177 & 9.7847 & 6.9951 & 6.3353 & 10.7529 & 10.2235 \\
$\beta_{2}$ & $(1.9633)$ & $(1.8669)$ & $(2.0105)$ & $(2.3393)$ & $(2.1672)$ & $(2.0085)$ \\
& -5.8532 & -5.4787 & -4.0050 & -2.8448 & -6.0698 & -5.7866 \\
$\beta_{3}$ & $(1.4708)$ & $(1.3986)$ & $(1.5061)$ & $(1.7525)$ & $(1.6235)$ & $(1.5047)$ \\
& -7.5519 & -7.0952 & -5.0205 & -3.3686 & -8.1690 & -7.6864 \\
Adj-R ${ }^{2}$ & $(1.9082)$ & $(1.8145)$ & $(1.9540)$ & $(2.2736)$ & $(2.1063)$ & $(1.9521)$ \\
RMSE & 0.9161 & 0.9208 & 0.8853 & 0.8599 & 0.8994 & 0.9068 \\
Foliar & 0.4308 & 0.4097 & 0.4412 & 0.5133 & 0.4756 & 0.4407 \\
$\beta_{0}$ & & & & & & \\
& -0.5319 & -0.2554 & -0.3327 & -0.4281 & -0.3156 & -0.2891 \\
$\beta_{1}$ & $(0.6356)$ & $(0.6586)$ & $(0.6758)$ & $(0.6862)$ & $(0.6332)$ & $(0.7068)$ \\
& $(2.8612$ & 6.8499 & 7.5184 & 6.4905 & 5.7485 & 8.2224 \\
$\beta_{2}$ & $(2.3574)$ & $(2.4426)$ & $(2.5064)$ & $(2.5450)$ & $(2.3485)$ & $(2.6212)$ \\
$\beta_{3}$ & -4.5992 & -4.7200 & -5.1298 & -4.2765 & -4.0239 & -5.8875 \\
& $(1.8117)$ & $(1.8772)$ & $(1.9262)$ & $(1.9559)$ & $(1.8048)$ & $(2.0144)$ \\
Adj-R & -4.2361 & -4.5066 & -5.1136 & -4.1277 & -3.2111 & -6.0750 \\
RMSE & $(2.3617)$ & $(2.4471)$ & $(2.5110)$ & $(2.5497)$ & $(2.3528)$ & $(2.6260)$ \\
\hline All & 0.6180 & 0.6114 & 0.6231 & 0.5757 & 0.5831 & 0.5402 \\
& 0.4189 & 0.4341 & 0.4454 & 0.4523 & 0.4173 & 0.4658 \\
\hline
\end{tabular}

All parameter estimates were significant at $\alpha=0.05$

${ }^{\mathrm{a}} \mathrm{RMSE}$ is the square root of the mean square error

driven by changes in accumulation of tree biomass. This may be one reason why relatively constant trends were observed between all elemental contents at the individual tree scale, particularly when DBH and height were used as predictor variables. These results generally agree with Wang et al. (1995) who found that aboveground nutrient accumulation in aspen tree stands in northeastern British Columbia reflected trends in biomass accumulation. Similarly, Peichl and Arain (2006) showed increased gains in aboveground ecosystem $\mathrm{C}$ over time, which were driven by increases in aboveground tree biomass. While we did not track changes over multiple years, we assumed variations in environmental factors were relatively low among our loblolly pine stand age-sequence due to similar parent material, site preparation, topography, vegetation, and climate, as indicated by the homogenous nature of reclamation methods used at this mine site and small spatial scale of our sampling locations.

Site resource availability plays a significant role in partitioning patterns among different biomass components (Albaugh et al. 2004; King et al. 1999). Low nutrient contents in an unmined loblolly pine plantation were directly attributed to low overall productivity of the site in South Carolina (Van Lear et al. 1984). While other studies have successfully modeled the response of tree size and ecosystem $\mathrm{C}$ to site index (Amateis et al. 2000; Amichev et al. 2008), we found no correlation between site index and elemental contents in aboveground biomass components in stands older than 10 years. 


\section{Stem}
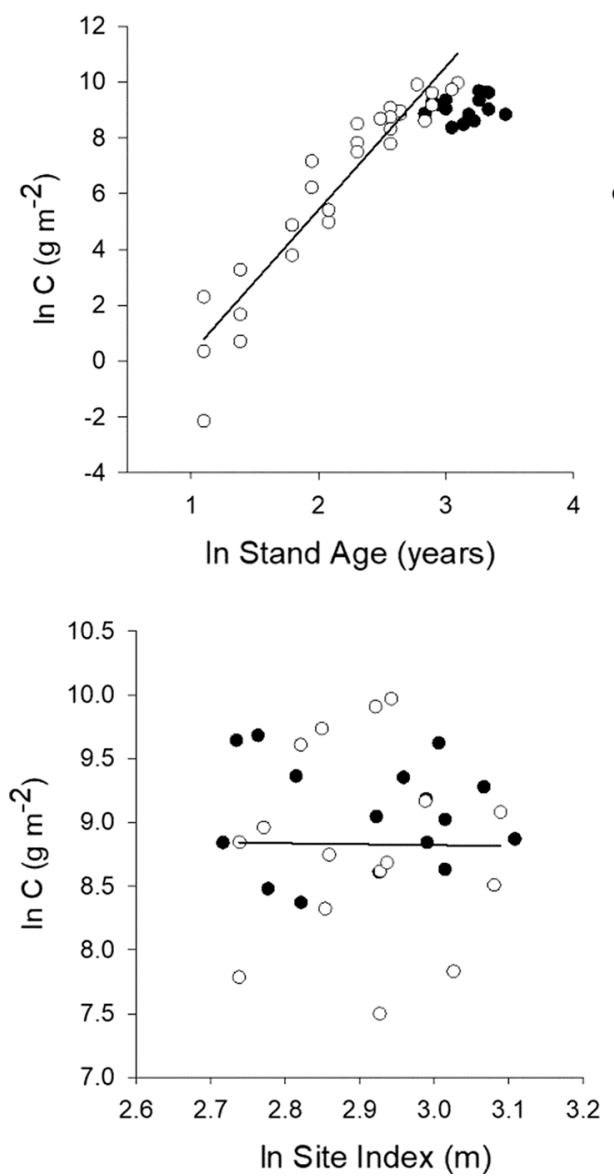

\section{Foliar}
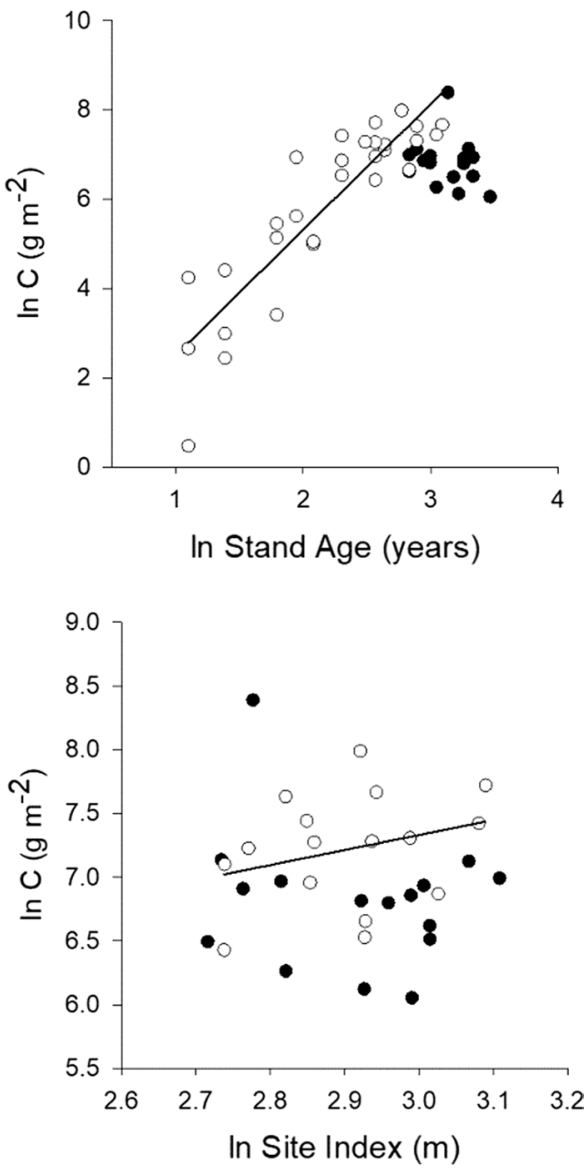

Fig. 2 Natural log of stand-level tree aboveground $\mathrm{C}$ versus stand age (years) and site index (m) for stem and foliar biomass components at a surface mine in east Texas. Thinned stands are not included in the statistical analyses and regression lines $(\alpha=0.05)$

Loblolly pine stands in our study exhibited a small range of site indices and obvious differences in site characteristics were not apparent. Likewise, it is probable that nutrient concentrations would not markedly vary among sites. Amateis et al. (2000) found that midrotation loblolly pine response (i.e., dominant height and basal area) to $\mathrm{N}$ and $\mathrm{P}$ fertilization was greatly impacted by drainage class, demonstrating the effects of site condition on loblolly pine productivity. Based on these conclusions, it seems reasonable for site index to not have significantly impacted our model. Instead, stand age and tree size were the strongest predictors of $\mathrm{C}$ and nutrients in loblolly pine.

In this study, several stands older than 17 years had been commercially thinned. As a result of harvest in first rotation loblolly pine, Rubilar et al. (2005) observed reduced nutrient availability on site and subsequent accumulation in aboveground biomass components 
Table 6 Pearson correlation coefficient matrix for stand-level aboveground elements and stand age and site index for stem and foliar biomass components at a surface mine in east Texas

\begin{tabular}{|c|c|c|c|c|c|c|c|c|}
\hline Variables & 1. & 2. & 3. & 4. & 5. & 6. & 7. & 8. \\
\hline \multicolumn{9}{|l|}{ Stem } \\
\hline 1. Stand age (years) & - & & & & & & & \\
\hline 2. Site index (m) & -.2585 & - & & & & & & \\
\hline 3. $\mathrm{C}\left(\mathrm{g} \mathrm{m}^{-2}\right)$ & $.9477^{*}$ & -.0114 & - & & & & & \\
\hline 4. $\mathrm{N}\left(\mathrm{g} \mathrm{m}^{-2}\right)$ & $.9465^{*}$ & -.0038 & $.9999 *$ & - & & & & \\
\hline 5. $\mathrm{P}\left(\mathrm{g} \mathrm{m}^{-2}\right)$ & $.9318^{*}$ & .0625 & $.9959 *$ & $.9970 *$ & - & & & \\
\hline 6. $\mathrm{K}\left(\mathrm{g} \mathrm{m}^{-2}\right)$ & $.9319^{*}$ & .1410 & $.9926^{*}$ & $.9939 *$ & $.9979 *$ & - & & \\
\hline 7. $\mathrm{Ca}\left(\mathrm{g} \mathrm{m}^{-2}\right)$ & $.9521^{*}$ & -.0648 & $.9995 *$ & $.9991^{*}$ & $.9927 *$ & $.9886 *$ & - & \\
\hline 8. $\mathrm{Mg}\left(\mathrm{g} \mathrm{m}^{-2}\right)$ & $.9500 *$ & -.0447 & $.9998 *$ & $.9996 *$ & $.9944 *$ & $.9907 *$ & $.9999 *$ & - \\
\hline \multicolumn{9}{|l|}{ Foliar } \\
\hline 1. Stand age (years) & - & & & & & & & \\
\hline 2. Site index $(\mathrm{m})$ & -.2585 & - & & & & & & \\
\hline 3. $\mathrm{C}\left(\mathrm{g} \mathrm{m}^{-2}\right)$ & $.8875^{*}$ & .2903 & - & & & & & \\
\hline 4. $\mathrm{N}\left(\mathrm{g} \mathrm{m}^{-2}\right)$ & $.8901 *$ & .2662 & $.9996 *$ & - & & & & \\
\hline 5. $\mathrm{P}\left(\mathrm{g} \mathrm{m}^{-2}\right)$ & $.8995^{*}$ & .2216 & $.9989 *$ & $.9995^{*}$ & - & & & \\
\hline 6. $\mathrm{K}\left(\mathrm{g} \mathrm{m}^{-2}\right)$ & $.8955^{*}$ & .2454 & $.9998 *$ & $.9996^{*}$ & $.9993^{*}$ & - & & \\
\hline 7. $\mathrm{Ca}\left(\mathrm{g} \mathrm{m}^{-2}\right)$ & $.8578^{*}$ & .4001 & $.9967 *$ & $.9962 *$ & $.9929 *$ & $.9954 *$ & - & \\
\hline 8. $\mathrm{Mg}\left(\mathrm{g} \mathrm{m}^{-2}\right)$ & $.8986^{*}$ & .1697 & $.9962 *$ & $.9971 *$ & $.9988 *$ & $.9968 *$ & $.9875^{*}$ & - \\
\hline
\end{tabular}

$* P \leq 0.05$

for second rotation loblolly pine, demonstrating the impact of harvest on stand productivity. Zhao et al. (2014) found that $\mathrm{C}$ did not substantially vary across a range of planting densities (1483-4448 trees $\mathrm{ha}^{-1}$ ), with an exception of the lowest planting density (741 trees $\left.\mathrm{ha}^{-1}\right)$. Removal of nutrients as a component of aboveground tree biomass is expected to occur on a recently thinned or harvested site (Bragg and Guldin 2010). This likely led to the rapid drop in aboveground $\mathrm{C}$ and nutrient contents in our loblolly pine stands following thinning operations, further providing support for the notion that biomass is the most influential factor affecting elemental aggradation.

\section{Loblolly pine $\mathrm{C}$ and nutrients: mined versus unmined lands}

Nutrient demands and biomass production of southern loblolly pine plantations evolve over time and with use of silvicultural treatments (Albaugh et al. 2004, 2008; Borders et al. 2004; Jokela and Martin 2000; King et al. 1999; Kyle et al. 2005; Samuelson et al. 2004). Mechanical site preparation is common prior to forest plantation establishment (Furtado et al. 2016), especially on highly trafficked reclaimed surface mines (Angel et al. 2018). Several pre-mining soil C and $\mathrm{N}$ cycling properties are restored within the first-rotation on reclaimed mined lands in Texas, typically within 10-20 years ( $\mathrm{Ng}$ 2012). This is reflected in our data which suggest that reclaimed loblolly pine accrue sufficient aboveground $\mathrm{C}, \mathrm{N}$, and other macronutrients over the course of one rotation, despite one-time fertilizer and liming applications. Additionally, aboveground elemental concentrations in loblolly pine trees growing on reclaimed mined lands are likely to be higher or similar to values recorded in the literature for intensively managed 
Fig. 3 Residuals of the model (1) for prediction of aboveground tree $\mathrm{C}$ for stem and foliar biomass components (natural log transformed)
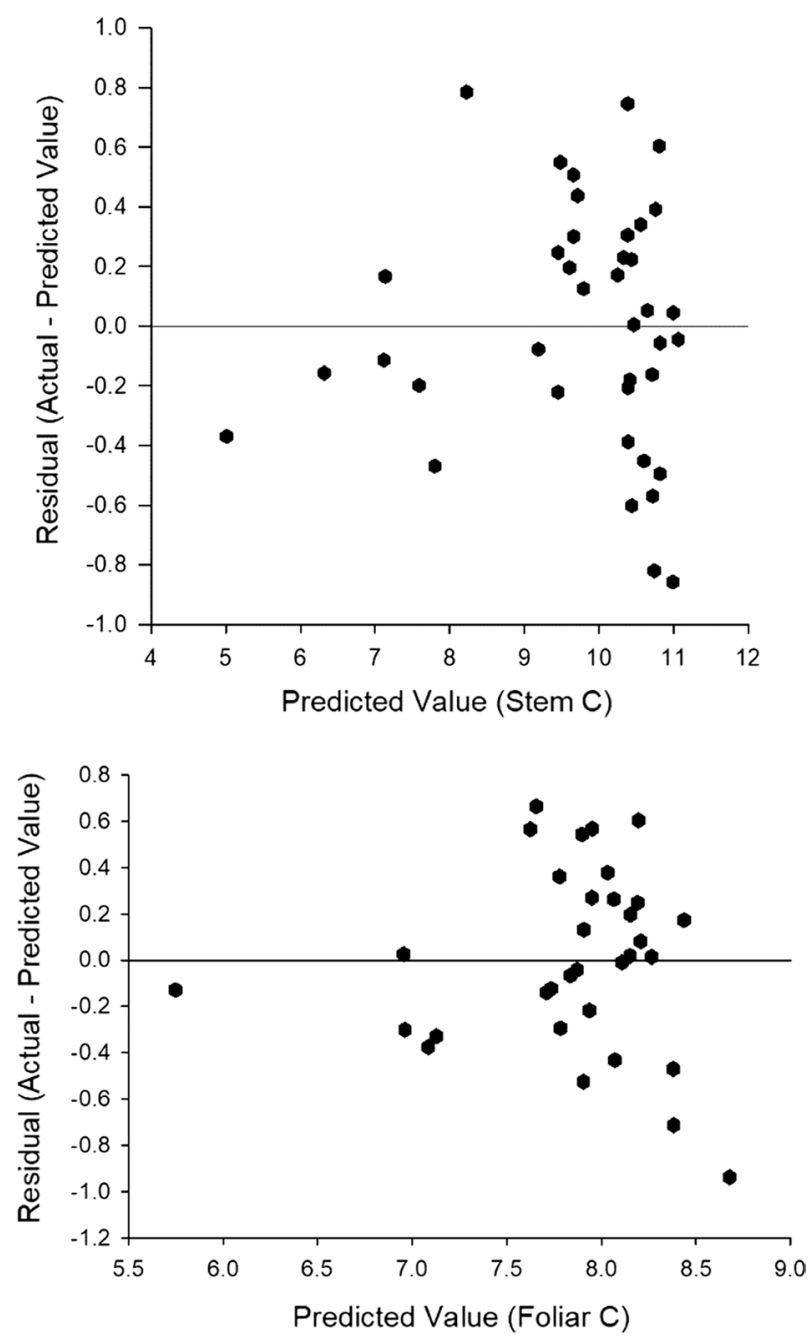

plantations on unmined lands, with foliar nutrients reaching above critical concentrations. These conclusions are based on comparisons of $\mathrm{C}$ and nutrient value confidence intervals for trees growing on mined lands (our study) and unmined lands from the literature (Albaugh et al. 2010; Rubilar et al. 2005; Zhao et al. 2014). We understand results are not reflective of direct comparisons and interpretations are limited due to differences in study design (i.e., chronosequence vs continuously monitored sample plots). The unmined studies assessed loblolly pine under similar silvicultural practices and in similar ecoregions, providing the best available reference levels for aboveground $\mathrm{C}$ and nutrients.

Furthermore, $\mathrm{Ng}$ (2012) found that mine soil $\mathrm{pH}$ values were similar to unmined lands and showed an increasing trend with age to a $0-30 \mathrm{~cm}$ depth when the mixed overburden reclamation method (MO) was used. The MO resulted in higher $\mathrm{C}$ and nutrient levels over time compared to other reclamation methods (Ng 2012). Since the MO was used in our study, these findings may partly explain the satisfactory elemental concentrations we 
observed relative to unmined lands. Priest et al. (2015), using the sample plots from our study, found that aboveground biomass of reclaimed loblolly pine trees in the Gulf Coastal Plain was similar to average biomass for loblolly pine growing on unmined lands. Thus, based on our indirect comparisons to the literature and similarities reported for stand-level pine productivity on mined and unmined lands (Priest et al. 2016), we infer that first-rotation loblolly pine trees from our study are likely aggrading some essential aboveground elements (i.e., stem P, Ca and foliar C, P, K) at similar rates to trees on unmined lands.

\section{Implications of related research}

Loblolly pine plantations have been planted outside of the species' native range (i.e., southeastern USA), including on reclaimed mined lands in Kentucky (Hansen et al. 2015) and on undisturbed lands in southern Brazil (Dobner et al. 2018). The former study found acceptable growth rates of loblolly pine for timber production, which for the region is considered a potential species for assisted migration in response to predicted climate change. These studies highlight the value of exploring long-term carbon and nutrient dynamics for important tree species, which may inform future research regarding climate change and subsequent forest management strategies (Guldin 2018). It has been suggested that C sequestration potential is high for managed pine plantations receiving intensive silvicultural treatments (Jokela and Martin 2000). This is particularly true for disturbed lands which serve as substantial sinks for rapid accumulation of organic $\mathrm{C}$ in soil and aboveground biomass (Fettweis et al. 2005; Macdonald et al. 2015; Sampson et al. 2006; Wick et al. 2009). Thus, establishment of forest plantations on drastically disturbed landscapes enhances the concept of new generation plantations (NGP), which recognizes sustainable use of a wide variety of forest plantations in providing societal needs (e.g., timber, wood fiber, bioenergy) and ecological benefits (e.g., C sequestration, biodiversity) (Silva et al. 2018).

Examples of combining the NGP concept and reforestation of reclaimed surface mines are diverse and include studies involving loblolly pine plantation productivity (Priest et al. 2016) and development of vegetative communities (Christian et al. 2017) on reclaimed lignite surface mines in the Gulf Coastal Plain, survival and growth performance of plantation style American chestnut (Castanea dentata (Marsh.) Borkh.) on reclaimed coal surface mines in Appalachia (Skousen et al. 2018), and survival and growth of multispecies plantations on reclaimed Canadian gold mines (Guittonny-Larchevêque and Pednault 2016). To date, there is limited information regarding aboveground forest $\mathrm{C}$ accumulation on surface mined lands. Zipper et al. (2007) estimated that pine species growing on mined lands have the potential of accumulating $0.2 \%$ of the projected US coal-combustion $\mathrm{C}$ emissions over a 30 -year rotation, which is an age class similar to the oldest stands used in this study. Similar to our results, Avera et al. (2015) found increases in tree $\mathrm{C}$ biomass over time on a reclaimed surface coal mine, and for trees older than 5 years, aboveground tree $\mathrm{C}$ represented the highest percentage of total ecosystem carbon followed by mineral soil (70-73\% and $12-16 \%$, respectively). Our study related aboveground loblolly pine $\mathrm{C}$ and nutrient dynamics to previous work on similar surface mines ( $\mathrm{Ng} 2012$ ), which explored soil $\mathrm{C}$ and nutrient dynamics. Belowground elemental pools provide essential information regarding C sequestration and nutrient cycling (Chen et al. 2017) and ideally should be coupled with aboveground measurements (Avera et al. 2015; Wang et al. 1995). Certain ecological services such as $\mathrm{C}$ sequestration are likely to be enhanced on drastically disturbed lands (Macdonald et al. 2015). However, reforestation efforts in general are linked to long-term gains in ecosystem $\mathrm{C}$ and research should focus broadly on soil and tree elemental dynamics of 
reforested sites across a diversity of landscapes, including all forms of management and land use histories (Nave et al. 2018). With projected changes in climate and increases in human-caused disturbances, the need to improve and conserve ecological services derived from managed forest plantations on mined and unmined lands becomes increasingly important on a global scale (Macdonald et al. 2015; Silva et al. 2018).

\section{Conclusions}

Our findings indicate that loblolly pine plantation productivity drives the stand-level response in aboveground $\mathrm{C}$ and nutrients over a typical sawtimber rotation, rather than differences in concentrations across stands of different ages. Declining elemental contents observed in thinned stands were likely a result of the corresponding decrease in standing tree biomass. Given the relatively good fit of our model for predicting stand-level C and nutrients using age, these results may aid in future research involving biogeochemical modelling of $\mathrm{C}$ and nutrients in loblolly pine plantations. Our data suggest that aboveground loblolly pine $\mathrm{C}$ and nutrient accumulation is comparable to reference values from the literature, and we expect concentrations to either follow or exceed stand-level trends on unmined lands over time. The various components of this study provide results which are applicable to surface mined lands and may offer insight to related research areas including aboveground $\mathrm{C}$ sequestration, tree nutrient dynamics, reforestation, and managed forest plantations.

Acknowledgements We thank the Arthur Temple College of Forestry and Agriculture at Stephen F. Austin State University for aiding in field data collection and laboratory work. Appreciation is also extended to the Luminant Environmental Research Program for funding and logistical support.

Funding Funding for this project was provided by the Luminant Environmental Research Program (Luminant Mining Company, LLC), Stephen F. Austin State University, and the McIntire Stennis Cooperative Forestry Research Program.

\section{Compliance with ethical standards}

Conflict of interest The steering committee for the Luminant Environmental Research Program is an advisory board consisting of several Texas university researchers serving in a pro bono capacity, including Hans Williams. Results of Luminant funded research are neither directed nor influenced by the Research Program's steering committee.

OpenAccess This article is distributed under the terms of the Creative Commons Attribution 4.0 International License (http://creativecommons.org/licenses/by/4.0/), which permits unrestricted use, distribution, and reproduction in any medium, provided you give appropriate credit to the original author(s) and the source, provide a link to the Creative Commons license, and indicate if changes were made.

\section{References}

Adegbidi HG, Jokela EJ, Comerford NB (2005) Factors influencing production efficiency of intensively managed loblolly pine plantations in a 1- to 4-year-old chronosequence. Forest Ecol Manag 218:245258. https://doi.org/10.1016/j.foreco.2005.08.016

Akala VA, Lal R (2001) Soil organic carbon pools and sequestration rates in reclaimed minesoils in Ohio. J Environ Qual 30:2098-2104 
Albaugh TJ, Allen HL, Dougherty PM, Johnsen KH (2004) Long term growth responses of loblolly pine to optimal nutrient and water resource availability. Forest Ecol Manag 192:3-19

Albaugh TJ, Allen HL, Fox TR (2008) Nutrient use and uptake in Pinus taeda. Tree Physiol 28:1083-1098

Albaugh JM, Blevins L, Allen HL, Albaugh TJ, Fox TR, Stape JL, Rubilar RA (2010) Characterization of foliar macro- and micronutrient concentrations and ratios in loblolly pine plantations in the southeastern United States. South J Appl For 34:53-64

Albaugh TJ, Allen HL, Stape JL, Fox TR, Rubilar RA, Price JW (2012) Intra-annual nutrient flux in Pinus taeda. Tree Physiol 32:1237-1258

Amateis RL, Liu J, Ducey MJ, Allen HL (2000) Modeling response to midrotation nitrogen and phosphorus fertilization in loblolly pine plantations. South J Appl For 24:207-212

Amichev BY, Burger JA, Rodrigue JA (2008) Carbon sequestration by forests and soils on mined land in the Midwestern and Appalachian coalfields of the US. Forest Ecol Manag 256:1949-1959

Andrews JA, Johnson JE, Torbert JL, Burger JA, Kelting DL (1998) Minesoil and site properties associated with early height growth of eastern white pine. J Environ Qual 27:192. https://doi.org/10.2134/jeq19 98.00472425002700010027x

Angel PN (1973) A soil analysis of the strip mine spoil bank at Fairfield, Texas Stephen F. Austin State University, M.S. Thesis, Nacogdoches, Texas

Angel H, Stovall J, Williams H, Farrish K, Oswald B, Young J (2018) Surface and subsurface tillage effects on mine soil properties and vegetative response. Soil Sci Soc Am J 82:475-482

Aspinwall MJ, McKeand SE, King JS (2012) Carbon sequestration from 40 years of planting genetically improved loblolly pine across the southeast. U S Forest Sci 58:446-456. https://doi.org/10.5849/forsc i. 11-058

Avera BN, Strahm BD, Burger JA, Zipper CE (2015) Development of ecosystem structure and function on reforested surface-mined lands in the Central Appalachian Coal Basin of the United States. New Forest 46:683-702. https://doi.org/10.1007/s11056-015-9502-8

Baldwin VC (1987) Green and dry-weight equations for above-ground components of planted loblolly pine trees in the West Gulf Region. South J Appl For 11:212-218

Barron-Gafford GA, Will RE, Burkes EC, Shiver B, Teskey RO (2003) Nutrient concentrations and contents, and their relation to stem growth, of intensively managed Pinus taeda and Pinus elliottii stands of different planting densities. Forest Sci 49:291-300

Borders BE, Will RE, Markewitz D, Clark A, Hendrick R, Teskey RO, Zhang Y (2004) Effect of complete competition control and annual fertilization on stem growth and canopy relations for a chronosequence of loblolly pine plantations in the lower coastal plain of Georgia. Forest Ecol Manag 192:21-37. https ://doi.org/10.1016/j.foreco.2004.01.003

Bragg DC, Guldin JM (2010) Estimating long-term carbon sequestration patterns in even-and uneven-aged southern pine stands. US Department of Agriculture Forest Service Proceedings RMRS-P-61, pp 111-123

Chatterjee A, Lal R, Shrestha RK, Ussiri DAN (2009) Soil carbon pools of reclaimed minesoils under grass and forest landuses. Land Degrad Dev 20:300-307. https://doi.org/10.1002/ldr.916

Chen G et al (2017) Soil aggregate characteristics and stability of soil carbon stocks in a Pinus tabulaeformis plantation. New Forest 48:837-853. https://doi.org/10.1007/s11056-017-9600-X

Chichester FW, Smith SJ (1983) Biological cycling of ${ }^{15} \mathrm{~N}$-labeled fertilizer nitrogen in lignite minesoil materials. Soil Sci Soc Am J 47:676-682. https://doi.org/10.2136/sssaj1983.03615995004700040014x

Christian C, Oswald B, Williams H, Farrish K (2017) Vegetative community development over 30 years within pine plantations on reclaimed mine land in east Texas. Forest Res 6:194. https://doi. org/10.4172/2168-9776.1000194

Ciolkosz EJ, Cronce RC, Cunningham RL, Petersen GW (1985) Characteristics, genesis, and classification of Pennsylvania minesoils. Soil Sci 139:232-238

Daniels WL, Amos DF (1985) Generating productive topsoil substitutes from hard rock overburden in the southern Appalachians. Environ Geochem Health 7:8-15

Dobner M, Nicoletti MF, Arce JE (2018) Influence of crown thinning on radial growth pattern of Pinus taeda in southern Brazil. New Forests. https://doi.org/10.1007/s11056-018-9669-x

Dolezel R (1975) Soil survey of Panola County, Texas. US Department of Agriculture, Soil Conservation Service

Fettweis U, Bens O, Hüttl RF (2005) Accumulation and properties of soil organic carbon at reclaimed sites in the Lusatian lignite mining district afforested with Pinus sp. Geoderma 129:81-91. https://doi. org/10.1016/j.geoderma.2004.12.034

Furtado BF, Morris LA, Markewitz D (2016) Loblolly pine (Pinus taeda L.) seedling growth response to site preparation tillage on upland sites. Soil Sci Soc Am J 80:472-489. https://doi.org/10.2136/sssaj 2015.06.0243 
Gholz H, Fisher R, Prichett W (1985) Nutrient dynamics in slash pine plantation ecosystems. Ecology 66:647-659

Gonzalez-Benecke CA et al (2014) Local and general above-stump biomass functions for loblolly pine and slash pine trees. Forest Ecol Manag 334:254-276

Guittonny-Larchevêque M, Pednault C (2016) Substrate comparison for short-term success of a multispecies tree plantation in thickened tailings of a boreal gold mine. New Forest 47:763-781. https:// doi.org/10.1007/s11056-016-9543-7

Guldin JM (2018) Silvicultural options in forests of the southern United States under changing climatic conditions. New Forests 29(6):62-78. https://doi.org/10.1007/s11056-018-9656-2

Haering KC, Daniels WL, Galbraith JM (2004) Appalachian mine soil morphology and properties. Soil Sci Soc Am J 68:1315-1325. https://doi.org/10.2136/sssaj2004.1315

Hall SL, Barton CD, Baskin CC (2010) Topsoil seed bank of an Oak-Hickory forest in eastern Kentucky as a restoration tool on surface mines. Restor Ecol 18:834-842

Hansen E, Barton C, Drayer A (2015) Challenges for native forest establishment on surface mines in a time of climate change. Reclam Matters Spring 2015:36-39

Hons FM (1978) Chemical and physical properties of lignite spoils and their influence upon successful reclamation. Doctoral Dissertation, Texas A\&M University

Howard J, Amos D, Daniels W (1988) Phosphorus and potassium relationships in southwestern Virginia coal-mine spoils. J Environ Qual 17:695-700

Johnsen K et al. (2004) Carbon sequestration in loblolly pine plantations: methods, limitations, and research needs for estimating storage pools. In: Southern forest science: past, present, and future. Forest Service Southern Research Station G.T.R. SRS-75. Asheville, NC, pp 373-381

Johnson DW, Todd DE, Tolbert VR (2003) Changes in ecosystem carbon and nitrogen in a loblolly pine plantation over the first 18 years. Soil Sci Soc Am J 67:1594-1601. https://doi.org/10.2136/sssaj 2003.1594

Jokela EJ (2004) Nutrient management of southern pines In Slash pine: still growing and growing! In: Proceedings of the slash pine symposium. Gen Tech Rep SRS-76. US Department of Agriculture, Forest Service, Southern Research Station, Asheville, NC, p 148

Jokela EJ, Martin TA (2000) Effects of ontogeny and soil nutrient supply on production, allocation, and leaf area efficiency in loblolly and slash pine stands. Can J For Res 30:1511-1524. https://doi. org/10.1139/x00-082

Jones DA, O'Hara KL (2016) The influence of preparation method on measured carbon fractions in tree tissues. Tree Physiol 36:1177-1189. https://doi.org/10.1093/treephys/tpw051

Justine MF, Yang W, Wu F, Tan B, Khan MN, Zhao Y (2015) Biomass stock and carbon sequestration in a chronosequence of Pinus massoniana plantations in the upper reaches of the Yangtze River. Forests 6:3665-3682

Kinerson RS, Ralston CW, Wells CG (1977) Carbon cycling in a loblolly pine plantation. Oecologia 29:1-10

King JS, Albaugh TJ, Allen HL, Kress LW (1999) Stand-level allometry in Pinus taeda as affected by irrigation and fertilization. Tree Physiol 19:769-778

Kyle KH, Andrews LJ, Fox TR, Aust WM, Burger JA, Hansen GH (2005) Long-term effects of drainage, bedding, and fertilization on growth of loblolly pine (Pinus taeda L.) in the Coastal Plain of Virginia. South J Appl For 29:205-214

Li RS, Daniels WL (1994) Nitrogen accumulation and form over time in young mine soils. J Environ Qual 23:166-172. https://doi.org/10.2134/jeq1994.00472425002300010026x

Loehle C, Idso C, Wigley TB (2016) Physiological and ecological factors influencing recent trends in United States forest health responses to climate change. Forest Ecol Manag 363:179-189

Macdonald SE et al (2015) Forest restoration following surface mining disturbance: challenges and solutions. New Forest 46:703-732

Maharana JK, Patel AK (2013) Physico-chemical characterization and mine soil genesis in age series coal mine overburden spoil in chronosequence in a dry tropical environment. J Phylogen Evolut Biol 1:1-7. https://doi.org/10.4172/2329-90021000101

Maier CA, Albaugh TJ, Lee Allen H, Dougherty PM (2004) Respiratory carbon use and carbon storage in mid-rotation loblolly pine (Pinus taeda L.) plantations: the effect of site resources on the stand carbon balance. Glob Change Biol 10:1335-1350. https://doi.org/10.1111/j.1529-8817.2003.00809 . $\mathrm{X}$

Mehlich A (1984) Mehlich 3 soil test extractant: a modification of mehlich 2 extractant. Commun Soil Sci Plant Anal 15:1409-1416. https://doi.org/10.1080/00103628409367568

Metz LJ, Wells CG (1965) Weight and nutrient content of the aboveground parts of some loblolly pines. US Forest Service Research Paper SE-17 
National Oceanic and Atmospheric Administration (2016) 1981-2010 normals: Carthage, TX. National Centers for Environmental Information, Asheville, NC

Nave LE, Walters BF, Hofmeister KL, Perry CH, Mishra U, Domke GM, Swanston CW (2018) The role of reforestation in carbon sequestration. New Forests 60(3):602-625. https://doi.org/10.1007/s1105 6-018-9655-3

Newbold RA, Baldwin VCJ, Hill G (2001) Weight and volume determination for planted loblolly pine in north Louisiana. Gen Tech Rep SRS-26. US Department of Agriculture, Forest Service, Southern Research Station, Asheville, NC, pp 1-24

$\mathrm{Ng} \mathrm{J} \mathrm{(2012)} \mathrm{Recovery} \mathrm{of} \mathrm{carbon} \mathrm{and} \mathrm{nitrogen} \mathrm{cycling} \mathrm{and} \mathrm{microbial} \mathrm{community} \mathrm{functionality} \mathrm{in} \mathrm{a} \mathrm{post-}$ lignite mining rehabilitation chronosequence in east Texas. M.S. Thesis, M.S. Thesis. Texas A\&M University

Peichl M, Arain MA (2006) Above-and belowground ecosystem biomass and carbon pools in an agesequence of temperate pine plantation forests. Agric For Meteorol 140:51-63

Prestemon JP, Abt RC (2002) Timber products supply and demand. Gen Tech Rep SRS-53. US Department of Agriculture, Forest Service, Southern Research Station, Asheville, NC, pp 299-325

Priest J, Stovall J, Coble D, Oswald B, Williams H (2015) Loblolly pine growth patterns on reclaimed mineland: allometry, biomass, and volume. Forests 6:3547

Priest JS, Stovall JP, Coble DW, Williams HM, Oswald BP (2016) Loblolly pine site index on reclaimed mineland in east Texas. Forest Sci 62:535-545. https://doi.org/10.5849/forsci.15-106

Rodrigue JA, Burger JA (2004) Forest soil productivity of mined land in the midwestern and eastern coalfield regions. Soil Sci Soc Am J 68:833. https://doi.org/10.2136/sssaj2004.0833

Rubilar RA, Allen HL, Kelting DL (2005) Comparison of biomass and nutrient content equations for successive rotations of loblolly pine plantations on an Upper Coastal Plain Site. Biomass Bioenergy 28:548-564. https://doi.org/10.1016/j.biombioe.2004.12.001

Sampson DA, Waring RH, Maier CA, Gough CM, Ducey MJ, Johnsen KH (2006) Fertilization effects on forest carbon storage and exchange, and net primary production: a new hybrid process model for stand management. Forest Ecol Manag 221:91-109

Samuelson LJ, Johnsen K, Stokes T (2004) Production, allocation, and stemwood growth efficiency of Pinus taeda L. stands in response to 6 years of intensive management. Forest Ecol Manag 192:59-70

Showalter JM, Burger JA, Zipper CE, Donovan PF (2007) Influence of mine soil properties on white oak seedling growth: a proposed mine soil classification model. South J Appl For 31:99-107

Shrestha RK, Lal R (2006) Ecosystem carbon budgeting and soil carbon sequestration in reclaimed mine soil. Environ Int 32:781-796. https://doi.org/10.1016/j.envint.2006.05.001

Shrestha RK, Lal R (2007) Soil carbon and nitrogen in 28-year-old land uses in reclaimed coal mine soils of Ohio. J Environ Qual 36:1775-1783. https://doi.org/10.2134/jeq2007.0071

Silva LN, Freer-Smith P, Madsen P (2018) Production, restoration, mitigation: a new generation of plantations. New Forests. https://doi.org/10.1007/s11056-018-9644-6

Skousen JG et al (2018) Plantation performance of chestnut hybrids and progenitors on reclaimed Appalachian surface mines. New Forests 49(5):599-611. https://doi.org/10.1007/s11056-018-9643-7

Ussiri DAN, Lal R (2005) Carbon sequestration in reclaimed minesoils. Crit Rev Plant Sci 24:151-165. https://doi.org/10.1080/07352680591002147

Van Lear DH, Kapeluck PR (1995) Above- and below-stump biomass and nutrient content of a mature loblolly pine plantation. Can J For Res 25:361-367. https://doi.org/10.1139/x95-040

Van Lear DH, Waide JB, Teuke MJ (1984) Biomass and nutrient content of a 41-year-old loblolly pine (Pinus taeda L.) plantation on a poor site in South Carolina. Forest Sci 30:395-404

Walker LR, Wardle DA, Bardgett RD, Clarkson BD (2010) The use of chronosequences in studies of ecological succession and soil development. J Ecol 98:725-736. https://doi.org/10.111 1/j.1365-2745.2010.01664.x

Wang J, Zhong A, Comeau P, Tsze M, Kimmins J (1995) Aboveground biomass and nutrient accumulation in an age sequence of aspen (Populus tremuloides) stands in the Boreal White and Black Spruce Zone. B C Forest Ecol Manag 78:127-138

Wick AF, Ingram LJ, Stahl PD (2009) Aggregate and organic matter dynamics in reclaimed soils as indicated by stable carbon isotopes. Soil Biol Biochem 41:201-209. https://doi.org/10.1016/j.soilb io.2008.09.012

Zhang S, Allen HL (1996) Foliar nutrient dynamics of 11-year-old loblolly pine (Pinus taeda) following nitrogen fertilization. Can J For Res 26:1426-1439. https://doi.org/10.1139/x26-159

Zhao D, Kane M, Teskey R, Markewitz D, Greene D, Borders B (2014) Impact of management on nutrients, carbon, and energy in aboveground biomass components of mid-rotation loblolly pine (Pinus taeda L.) plantations. Ann Forest Sci 71:843-851. https://doi.org/10.1007/s13595-014-0384-2 
Zipper CE, Burger JA, McGrath JM, Amichev BY (2007) Carbon accumulation potentials of post-SMCRA coal-mined lands. In: Proceedings of 24th annual meeting, American Society of Mining and Reclamation, Gillette, WY, pp 962-980

Zipper CE, Burger JA, Skousen JG, Angel PN, Barton CD, Davis V, Franklin JA (2011) Restoring forests and associated ecosystem services on Appalachian coal surface mines. Environ Manag 47:751-765. https://doi.org/10.1007/s00267-011-9670-z

Zipper CE, Burger JA, Barton CD, Skousen JG (2013) Rebuilding soils on mined land for native forests in Appalachia. Soil Sci Soc Am J 77:337-349. https://doi.org/10.2136/sssaj2012.0335 